\title{
マダガスカル南部半乾嬠地域の水資源について
}

\author{
森 和雄*
}

\section{Water Resources of the Southern Semiarid Area of Madagascar}

\author{
Kazuo MORI*
}

\begin{abstract}
This paper outlines the water resources of the southern area of Madagascar, which is based on the field investigation and several reports concerning with the potable water development plan requested from the government of Madagascar.

The area, under the tropical semiarid climate, is classified geographically into the Mahahaly Plateau, the Karimbola Plateau and the Ambovombe Basin, from the west to the east. The average annual precipitation over the area is about $350 \sim 600 \mathrm{~mm}$ and it decreases westward. The Karimbola Plateau and the Ambovombe Basin, where the population density is about 15 per one square kilometer, are underlain by continental sediments ranging in age from Tertiary to Quaternary. The Mahahaly Plateau is occupied by Tertiary limestone which yields little groundwater, so that the plateau is not inhabitable.

European Communities have been giving assistance to construction of a pipeline from the Menarndra River to the Karimbola Plateau for supplying potable water. On the other hand, Japan will support to develop water resources in the Ambovombe Basin. About 87,000 people living in a hill, coastal side of the basin, are in great trouble from lack of water. Apart from the hill, they manage to gain perched groundwater as well as surface water. It is very difficult to get water in the hill because the groundwater level is deep, mo:e than 100 meters from the surface, and an inplubia easily dries up at summer season.

It is recommended to install more inplubias, to inquire deep groundwater as well as perched groundwater and to increase water wagons for the improvement of water supply.
\end{abstract}

* 地梊調查所, Geological Survey of Japan. 


\section{I まえがき}

筆者は国際協力事業団の委託で, 1979年 3 月から 4 月の間に, マダガスカル南部半乾燥地域の水資源 の開発を目的とした事前調査に，調査団の一員とし て参加した。調査団は, 曾我部正敏 (団長; 地質調 查所）・寺蔆勝二（建設省河川局）・三村清志（建 設省河川局）・美和島克彦（国際協力事業団）・加 藤和憲（通訳）と筆者の計 6 名で構成された。調査 の結果については，国際協力事業団(1979)に公表さ れている。またそれに基づき基本設計調査が，日本 技術開発株式会社によって1980年に行われており， その成果として国際協力事業団(1981)がある。この 場合筆者は現地調查には参加していないが，作業管 理委員の一員として報告書作成に関与した。

これらの資料を基にして，発展途上国に入るであ ろらマダガスカル国の中です，とくに水不足のた め, 後進地域となっている南部地域の水資源につい て，手短に緒めてみたものである。

南部地域は, 西海岸に面するマハハリ高原・その 東側に位置するカリンボラ高原・さらに東側のアン ボボンベ盆地の 3 つに区分される。そのらちのマハ ハリ高原については，人口密度が極度に小さく，ま た不毛の石灰岩台地が大部分を占めて拉り, 当初か ら調査対象外であった。

マダガスカル国政府は，1979年の事前調査前，数 年来わが国に対し，カリンボラ高原とアンボボンベ

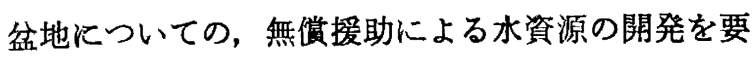
請してきていたのである。したがって事前調查団 む,この 2 つの高原・盆地を調查すべく、、ダガス カルに向ったのである。しかし首都タナナリブでの マダガスカル国政府の現地説明の中で，その1つの 対象地カリンボラ高原については，E C（ヨーロッ パ共同体）によるF E D資金で，同高原を横断する パイプライン計画が具体化していることを知らされ た。このパイプライン計画の水源は, カリンボラ高
原の西端を流れるメナランドラ川の伏流水を対象と した深度 $20 \mathrm{~m}$ の本井・予備井の 2 井であり, 水源 井は既に完成しているといらことであった。この事 業が実施されれば，カリンボラ高原の水不足の問題 は，大かた解決されるむのである。したがってわれ われの当地域の調査対象箐囲は，カリンボラ高原の 東部を含むが，主力をフンボボンベ盆地とすること に変更した。

\section{II マダガスカル島の概要}

マダガスカルは, 南半球のほぼ熱帯圈に位置し, アフリカ大陸の東侧インド洋上に孤立する島国であ る。比較的小さな島といった感じを受けるが，わが 国の 1.6 倍の面積がある。

\section{1 地形と地質}

同島の地形は，東部海岸平野地帯・中部高原地帯 ・西部海岸地帯の 3 つに大別することができる。以 下に 3 地帯の地形・地質の特徽を述べる。

\section{1) 東部海岸平野地帯}

インド洋と中央高原地帯に挾まれ，平均 $50 \mathrm{~km}$ の 幅をむつ狭い平坦地で, 多くの丘や沼地, 溶岩台地 などが散在し, 中央高原との境界は, $700 \mathrm{~m}$ もの断 崖になっているところむある。一方構成地質は，海 岸線に平行して細長く分布する白亜䄫の堆積岩およ び同時代の火山岩が主体となっている。

2 ）中央高原地帯

マダガスカル島の過半を占め, 広い面積を有す る。この中忙本島最高峰のツアラタナナ山 $(2,880$ m) があり，首都タナナリブ $(1,400 \mathrm{~m})$ るこの地帯 に含まれている。

この地帯を構成する岩石の殆んどは，先カンブリ ア系の岩石と, それを貫く花崗岩, チャーノカイト などである゚

\section{3 西部海岸地帯}

中央高原地帯の起伏のある地形に対し，その西伹 は，海岸までの間では，起伏が綬くかつ，西方に向 
って序々に高度を減じている。当地帯を構成する地 層は，先カンプリブ系の岩石を覆って分布する二骨 䟕以降の地層群であり，西方飞向って古い地層から 新しい地層が分布する。

下部はカルー渞群と呼ばれ，主として陸成層から なり，上部に向うにしたがって海成層となる。カル 一層群は二畳紀からジュラ紀にまたがるものでる。 この上には, ジュラ紀・白亜紀・古第三紀・新第三 紀・第四紀と海成あるいは陸成の地層が分布してい る。ジュラ紀拉よび古第三紀層中には，顕著な石灰 岩が㣣在するが，西側海岸の主要都市マジュンガに はそれを原料とする，この国唯一のセメント工場が ある。南部地域のマハハリ高原・カリンボラ高原・

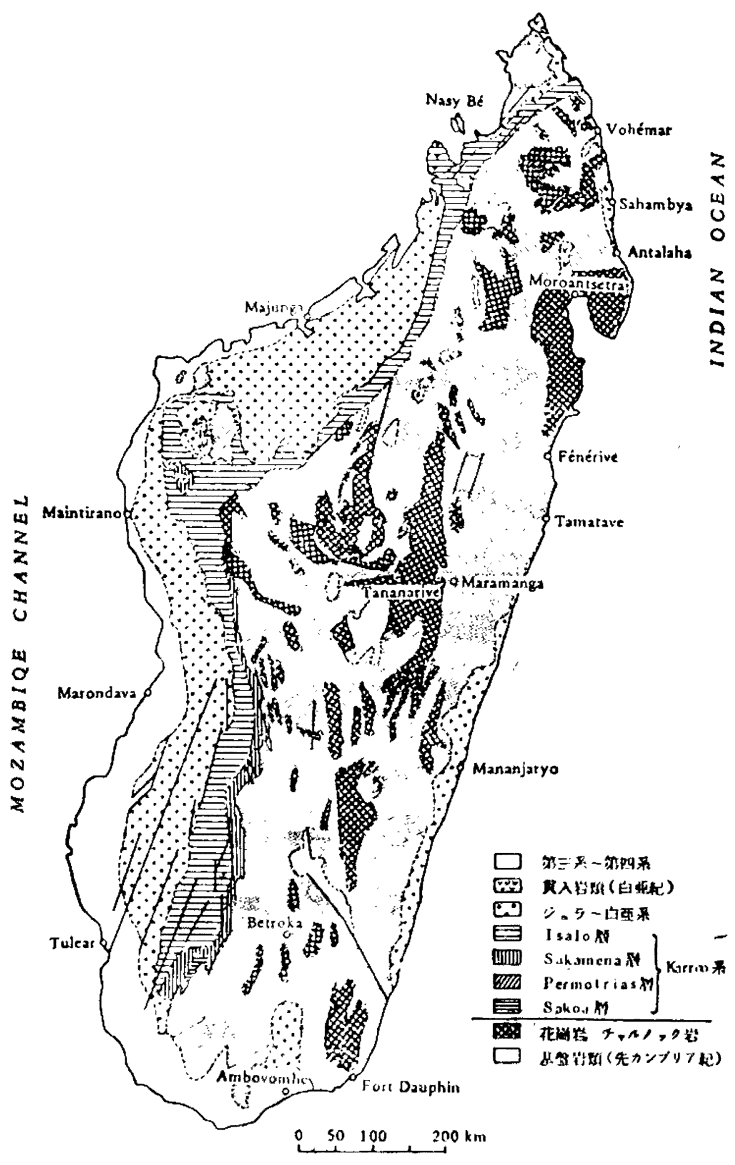

図一1 マダガスカルの地算概略図

(H. Besalrle, 1960 から編集)

Fig. 1 Geology of Madagascar (modified from Besalre, 1960).
アンボボンベ盆地は，分類上西部海岸地帯に入る。

2 雨 量

雨量については総体的にみると，わが国のそれに 匹敵する程で，対象の南部地域を除けば，水に恵ま れた国といってよい。とくに東海岸一带では，東あ るいは北東から吹く，貿易風，モンスーンによって もたらされる雨が中央高原にさ光ぎられるため， $3,000 \sim 3,500 \mathrm{~mm} /$ 年といった多雨地帯となってい

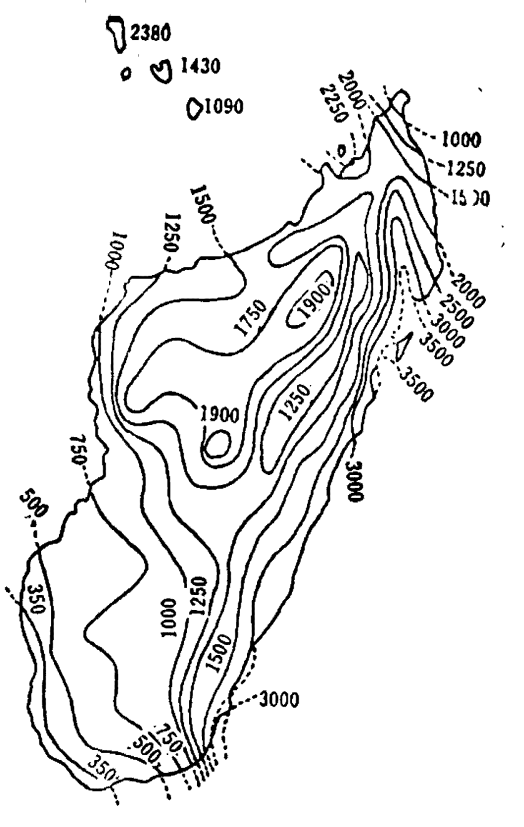

図一２ マダガスカルの等量雨線 $(\mathrm{mm} /$ 年)

Fig. 2 Annual rainfall in Madgascar ( $\mathrm{mm} / \mathrm{yebr}$ ).

る。また中央高原地帯および西部海岸地帯の北半部 では, $1,000 \sim 2,000 \mathrm{~mm} /$ 年であり,ここでも決し て少ない雨量ではない。このように全般的には水に 恵まれた国でもあり，人種的にも，東南アジア人の 血を多く引きつぐといったことから，往時から水を 必要とする稻作が盛んに行われている。

\section{III 南部地域の概要}

\section{1 地形および地質}

南部地域は地形的に，2つに区分すると (1)古第 三系・新第三紀・第四紀の堆積物で構成される高原 
おさよび盆地と呼ばれる堆積層地帯, (2)前者と同じ水 系に属する背後の基盤岩地帯（主として先カンブリ ア系の岩石分布地域）となる。

堆積層地帯に属するマハハリ高原の大部分は, 古 第三采の石灰岩で構成され，一方カリンボラ高原， アンボボンベ盆地は, 新第三紀特よび第四紀の堆積 層からなり，その下位は白亜紀の立武岩が存在する ところもあるが，大部分は，直接先カンブリア系岩 石に接している。

カリンボラ高原・アンボボンベ盆地はともに海岸 砂浜から急に高い砂丘が発達するが，前者は内陸側 へ向って緩く高度を増して高原の形をなす。一方後 者は海岸に近い砂丘が，約 $10 \mathrm{~km}$ 幅で標高 $150 \mathrm{~m}$ $300 \mathrm{~m}$ 級までの高まりを示し，それが内陸側へ高度 を減じて铑地状を呈している。

\section{2 気象}

当地域の気候は, 熱帯性半乾燥気候に属する。乾 季と雨季は明確に分れ，4 月から10月迄続く乾季に は, 雨量も少なく気温も比較的低い。一方11月から 3 月までの雨季には気温も高く降雨が集中し，雨季

・乾季が明膫に分れている。

困一 2 の等雨量線に示されるよらに, 東海岸の当 地域所管の県都フォト・ドーファン（困一 1 参照）
付近では，2,000 3, $000 \mathrm{~mm} /$ 年の多雨地帯である のに対し，一山越えた西側のアンボボンベ盆地の郡 都フンボボンヘでは $600 \mathrm{~mm} /$ 年, マハハリ高原の西 部では $350 \mathrm{~mm} /$ 年と西南西に向って,雨量は極端に 少なくなっている。

\section{3 河川の流況}

マダガスカルの国土は，厚いラテライトで覆われ る関係上，殆んどの河川水には，そのラテライトが 混入しており，一般に赤褐色の澤水となっている。 南部地域の河川もその例にもれない。

本地域には州都ッレアール市の南部を流れる, (1) オニヒラ川, 以下南から東へ向って, (2)リンタ川, (3)メナランドラ川, (4)マナンボボ川, (5)マンダラー 川の 5 河川がある。そのらち年間を通じて，表流水 のあるものは(1)，(3)，(5)の3 河川である。(4)のマナ ンホホボル 1 年のらち 2 ケ（ 6 月・ 7 月）が流量 が零となる。一方(2)のリンタ川は，1 年のらち流量 のある月はわずかに 4 ケ月たけである。（表一1参 照)

4 人口分布之家畜・産業

本地域の総面積は， $60,400 \mathrm{~km}^{2}$ あり，それに対 して，人口は約 50 万人といわれ，人口密度は，平均 8.3 人 $/ \mathrm{km}^{2}$ であるが，図ー 3 に示すように，マハハ

\section{表一1 主要河川の流 況}

Table 1 Flow regime of major rivers.

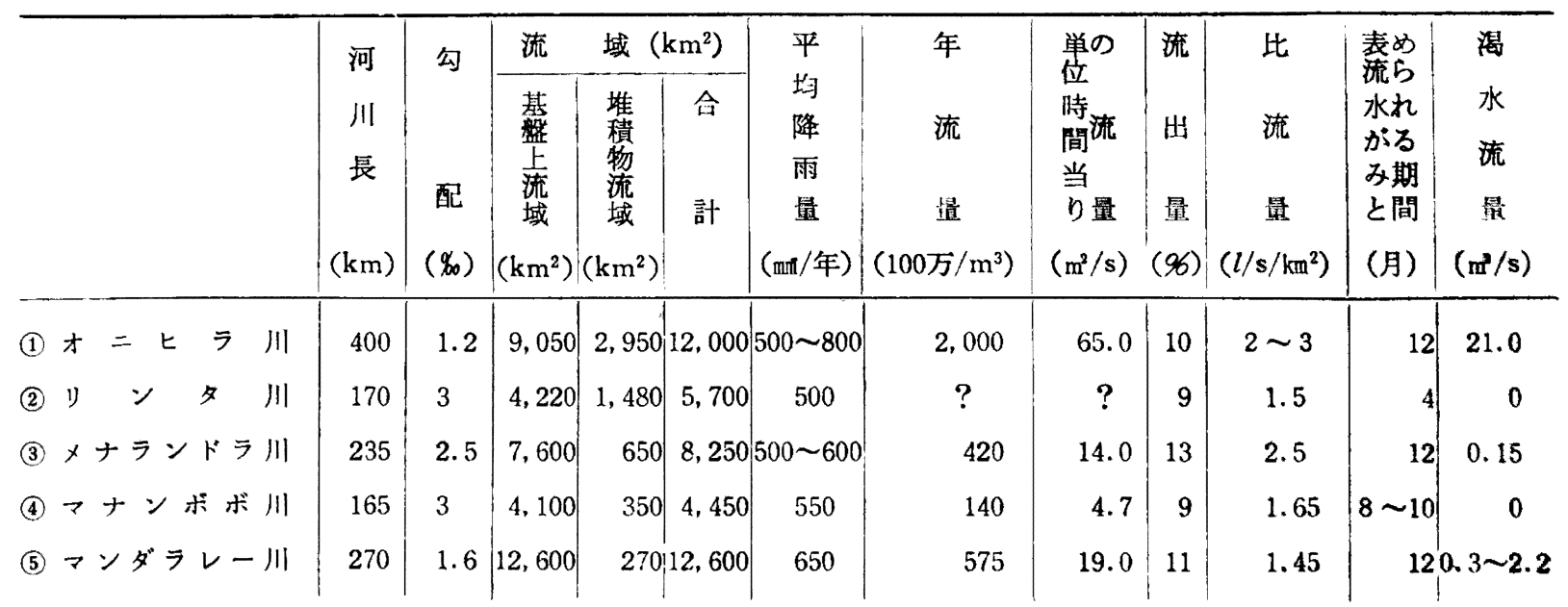

PROGRAMME DES NATIONS UNIES POUR LE DEVELOPPEMENT (1971) から引用 


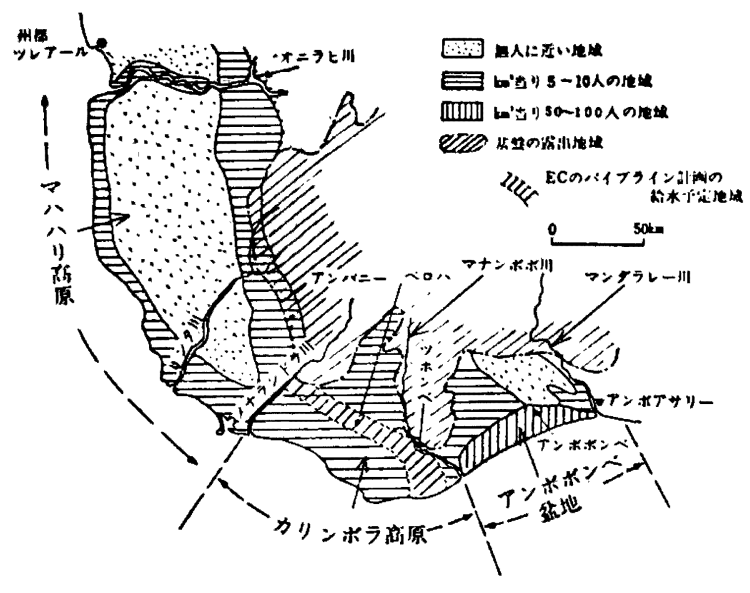

图一3 南部地域の区分と人口分布

Fig. 3 Physical regions and population in the South.

リ高原の大部分は土壤もやせ, 水多得にくいことか ら, 大部分は無人地帯となっている。カリンボラ高 原とアンボボンベ盆地に限ると，その人口密度は約 15 人 $/ \mathrm{km}^{2}$ となる。またアンボボンべ盆地の北部東 半分一帯も，森林地帯であり無人地帯となってい

\section{表一2 面積と人口}

Table 2 Area and population.

\begin{tabular}{|c|c|c|c|}
\hline & & $\begin{array}{l}\text { 面 皘 } \\
\left(\mathrm{km}^{2}\right)\end{array}$ & 人口 \\
\hline $\begin{array}{l}\text { 南 } \\
\text { 部 } \\
\text { 地 } \\
\text { 域 }\end{array}$ & $\begin{array}{l}\text { 基 盤 岩 地 帯 } \\
\text { 堆 皘 層 地 帯 }\end{array}$ & $\begin{array}{l}36,700 \\
23,700\end{array}$ & $\begin{array}{l}280,000 \\
220,000\end{array}$ \\
\hline 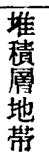 & $\begin{array}{l}\text { マハハリ高原 } \\
\text { カリソボラ高原と } \\
\text { アンボボンヘ地 }\end{array}$ & $\begin{array}{r}13,600 \\
9,250\end{array}$ & $\begin{array}{r}75,000 \\
135,000\end{array}$ \\
\hline
\end{tabular}

る。一方アンボボンベ盆地の海岸侧の標高 150 $300 \mathrm{~m}$ 級の砂丘高台一帯は, $50 \sim 100$ 人 $/ \mathrm{km}^{2}$ と，当 地域としてはもっとも人口密度が高くなっている。 この一带を今後「海岸寄り高台」と呼ぶ。

な打南部地域を基盤岩地帯とその下流の堆磧層地 带（盆地・高原）に分けた場合の，それぞれの総面 積と人口を表一 2 上部に示したが，雨者の人口密度 については大差がない。

基盤岩地带では, 住居が沢周辺となっており，表 流水が容易に得られることから，生活用水にはそれ 程苦労していないのに対し，その下流側の堆樍風地
帯の住民の大部分が慢性的な水不足に悩んでいる。 一方当地域では，古来より牧畜が盛んであり，牛 は 120 万頭（マダガスカル全体の $80 \%$ を占める）， 他に羊・山羊合わせて 130 万頭が飼われている。し かしフフリカ民族共通の風習である「牛をより多く 持つことが富の象徵」がここです根強く存在してい る。したがって牛が食肉商品等として買売されるこ とが割合に少なく，もっばら牛の数を增やすことに 専念するといった習慣が今な技持しているといわ れ，当地域の牧畜は一見盛んなように見える割に はそそれよる収入は以外と少ない。またこのこと は，適正な放牧密度を超㝋て，放牧されることにつ ながり，草原の植生の質の低下もさることながら， 当地域の水不足に拍車をかける結果となっている。

農業については, 草原の一部に, 自家用程度のマ ニオク，サツマ芋，と括もろこしなどが作られてい る。一方マンダラレー川流域の両岸(長さ約 $45 \mathrm{~km}$, 幅約 $5 \sim 6 \mathrm{~km}$ ) の広大な沖積低地の大部分には, フ ランス植民地時代にサイザル麻のプランテーション が設けられて拈り，その後マダガスカル独立によ り，同国に引きつがれている。このサイザル麻は南 部地域のもっとも重要な輸出品となっている。

\section{NV アンボボンベ盆地の水資源}

$$
\begin{aligned}
& 1 \text { フンボボンベ盆地一带の水不足 } \\
& \text { マナンボボ川やマンダラレー川から距離があり, }
\end{aligned}
$$

地下水の得にくい海岸寄り高台の人口密集地帯で は，乾季になると深刻な水不足に悩まされる。すべ ての集落に設置されているものではないが，公共の 天水溜が怙渴する。地方行政機関所属の給水車（現 在は 4 台稼動， 1 台 $4 \sim 5 \mathrm{~m}^{3}$ 皘及）が巡回するが, その然料得が不足し，思うょうには走れず，また道 〔路事情により，全く給水の行われないところあある といら。一方では水壳り商壳が盛んに行われ，河川 水あるいは井戸水をドラム缶 $2 \sim 3$ 本にいれ，牛車 に積儿で壳り歩く。住民自身も何 $10 \mathrm{~km}$ も離れた水 
のある場所に，水を求めて歩きまわることになる。 水の得にくい土地の住民は，乾季になると，収入の 大部分を水の購入に費やさなければならない。一方 後述の宙水地帯の浅井戸水源の殆んどは，私有物で あり，自家用以外の余剩な水は，水不足の地区住民 に売買されて扣り，その水源は貴重な私有財産とな っている。

当地域の慢性的水不足に追いらちをかけるのが, 約10年周期に襲う旱魅であり，その結果住民の 5 倍 も居る家留（牛・羊・山羊）に大きな犠牲が出ると いらことである。

2 河川水およびその伏流水

ツホンベ町の水源は, マナンボポ川左岸の伏流水 を取水するものであり，水源井の深度は $7 \mathrm{~m}$ であ る。ポンプの動力には，経損がかからない太陽熱と フレオンガスの組合わせた装置が用いられて拉り， $10 \mathrm{~m}^{3} /$ 時 の揚水が可能といらことであった。但し調 查当時は, 動力系が故障し, 予備のヂーゼルェンシ ンが使用されており，燃料費の捻出が困難であると いらことであった。いずれにせよ小規模ではある が，この地方唯一の公共水道施設である。ここでは かつてはマナンボボ川の表流水を生活用水として利 用していたが，乾季には表流水がなくなるため，伏 流水を取水する水道方式が設置されたものである。 しかし調查当時のマナンボボ川の塩分濃度が 700 $\mathrm{mg} / \mathrm{l}$ に対し, 水道水源井の塩分濃度は $2,500 \mathrm{mg} / \mathrm{l}$ といら大きな差を示していた。このことは，乾季に 批いてマナ゙ンボボ川表流水が，蒸発敬によって干上
るため, その一帯に塩頑を残存させる結果となり, 伏流水の塩分濃度を高めているものであろう。 一方マンダラレー川流域のサイザルのプランテー ションでは，同河川水を集水井に導入して取水し， サイザルの瀻維を取るための洗淮用水に使用されて いる。年間を通じて流量のあるマンダラレ一川の塩 分濃度は $130 \mathrm{mg} / \mathrm{l}$ (アンボサリ町附近で測定）で, マナンボボ川に比べ良質である。

両河川ともに, 流域には伏流水が広範囲に分布す ると考えられるが，付近の住民は，直接河川水を汲 み生活用水としている。また公共の給水車の水は, マンダラレー川の表流水とツホンべの水道水が利用 されている。

3 天水溜

地下水および表流水の取得の困難な海岸寄り高台 一帯には，当盆地人口の約70\%に相当する 87,300 人 が住んで拉り，その中に30数箇の天水溜が設置され ている。天水溜は, 図一4のような構造であり, 集

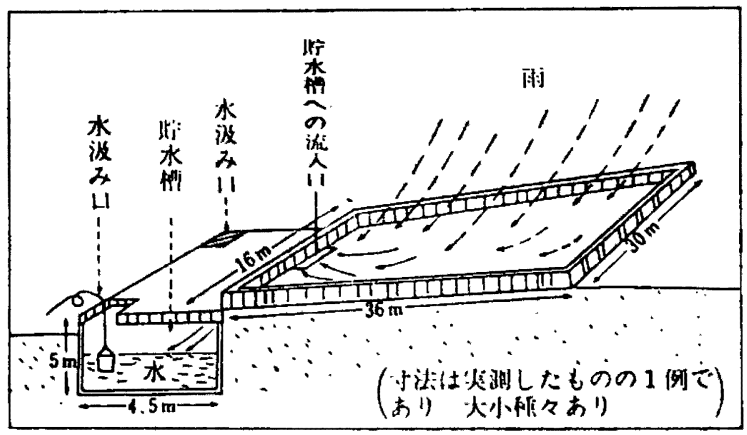

図一 4 天水溜

Fig. 4 Inplubia (Cistern system).

表一 3 河川の月平均流量 $\left(\mathrm{m}^{3} /\right.$ 秒)

Table 3 Mean monthly discharge $\left(\mathrm{m}^{3} / \mathrm{sec}\right)$.

\begin{tabular}{|c|c|c|c|c|c|c|c|c|c|c|c|c|c|}
\hline $\begin{array}{lll}\text { 河 } \quad \text { 名 } \\
\text { （観 测 地） }\end{array}$ & 11月 & 12月 & 1 月 & 2月 & 3月 & 4 月 & 5 月 & 6 月 & 7 月 & 8 月 & 9 月 & 10月 & 期間 \\
\hline 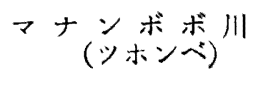 & 1.5 & 12.7 & 17.6 & 11 & 2.8 & 1.2 & 0.4 & 0 & 0 & 0.2 & 0.3 & 0.3 & $\begin{array}{l}1961 \\
\sim 1965\end{array}$ \\
\hline $\begin{array}{c}\text { マソダラレー川 } \\
(\text { アンボサリ) }\end{array}$ & 22 & 200 & 200 & 140 & 150 & 50 & 22 & 1.6 & 9.8 & 14 & 13 & 12 & $\begin{array}{l}1951 \\
\sim 1966\end{array}$ \\
\hline
\end{tabular}


水庭と眝水槽からなり、コンクリートモルタル製で ある。また集水庭の面積は $700 \mathrm{~m}^{2} \sim 1,500 \mathrm{~m}^{2}$ 間の ものが多い。一般に周囲は家畜の侵入を防止するた め、木の相でかこわれている。これらの天水溜は, 古いものああるが，1975～1977年の間に，FE D資 金により施行されたものが過半数を占めている。

天水溜の使用可能な期間は, その年の雨量・使用 人数・配分量に左右されるが，現状では年間のうち $5 \sim 6$ ケ月程度であり, 殆んどの天水溜は乾季まで 水を保持することはないようである。

天水溜に䬯水される水量は，小量の雨量の場合は 集水庭で蒸発散され，雨量計で計られた雨量よりは， 大部少な目となるものと考兄られる。仮に有効雨量 を $400 \mathrm{~mm} /$ 年, 集水庭面皘 $900 \mathrm{~m}^{2}$ とすると, 詝水 槽に流入する年間水量は $360 \mathrm{~m}^{3}$ となり, 1 人当り仮 に $5 l$ 日（生活するための最低限に近い水量）の使 用量とすると約 200 名弱が一つの天水溜に依存でき る計算となる。 87,000 名の海岸寄り高台の人口を天 水溜でまかなうには，莫大な数が必要となる。

\section{4 水溜り}

政府発行の 10 万分の 1 の地形図には, すり鉢状の 直径 100 500 m の窪地が図示されている。この窪 地はとくに盆地の海岸寄り高台に密集し，そこでは 平均すると $1 \mathrm{~km}^{2}$ に 1 ケ程度の割で分布している。 このような䆶地のうちの一部は，雨季には水溜り となり，住民の生活用水または家畜用として，広く 利用されている。それらのらちの透水性の悪い宔地 では, 雨季あけでも水を保持している。

5 地下 水

南部地域の地下水については，深刻な水問題をか かえている関係から，フランス植民地時代から現在 まで䦩に，数多くの調查・研究が行なわれ，水文地 質学的な資料が比較的充実している。その間に試錐

・深井戸のさく井など，地下水開発が数多く行われ ているのであるが，未だに効果が上ったとはいえ難 い状態であり，その難しさがらかがえる。
アンボボンベ盆地の地下水は，前述の 2 河川の流 域冲積低地の伏流水を別にして，次の 2 つに大別さ れる。1）盆地内の広籁囲にほぼ一様に分布する深 部地下水と，2）極部的に限られ，大小 2 地区に分 布する宙水である。

\section{1）深部地下水}

（1）基盤岩と堆積風

堆積凮は，基盤岩を不整合に澓い，盆地北側では 薄く, 南の海岸寄り高台では厚く分布している。こ の堆積層は新第三紀層と第四紀層からなるが，その 境界などは，研究者によって異なった解釈が行なわ れている。そのうちで最も新しいRAKOTONDRAINIBE Jean Herivelo (1976) によれば, 図一 5 の $\mathrm{A}$ - B 断面に示すよらな分類が行なわれている。 また同論文によれば，新第三紀層は陸成堆積物で， 粘土岩・粘土質砂岩・砂岩・砶岩からなり, 粘土質 砂岩と粘土岩が卓越する。一方第四紀層は新第三系 を不整合に覆い，主として砂からなり，一部に石灰 岩質砂岩を含んでいる。

また当地域の基盤岩は比較的浅部に存在する関係 上，基盤岩に到達している井戸が多くあり，それら を基として図一 5 が作成されてる。この図によると 基盤岩は 6/1,000 程度の非常に綏い勾配で, 南東 方向に傾斜している。

（2）帯水層と地下水位

深部地下水の带水層は, 北半部では新第三紀層, 南半部では第四紀層となっている。地下水位は基盤 岩にほぼ平行した形で，上記㬝の下部付近に保たれ て拈り, 被圧度の小さな地下水と推定される。図一 6 はアンボボンべ盆地とカリンボラ高原の東部で, かつて掘さくされた深井戸の記録を示したものであ り，例竞ば海岸寄り高台に位置するD 9, D 8，D 10の井戸では，地上からの水位が $120 \mathrm{~m}$ から $170 \mathrm{~m}$ など極端に深くなっている。一方北部の基盤岩の簬 出する付近では，地表のごく近くに地下水が分布 し, 数 $\mathrm{m}$ から10 数 $\mathrm{m}$ で到達する。したがってコンク 


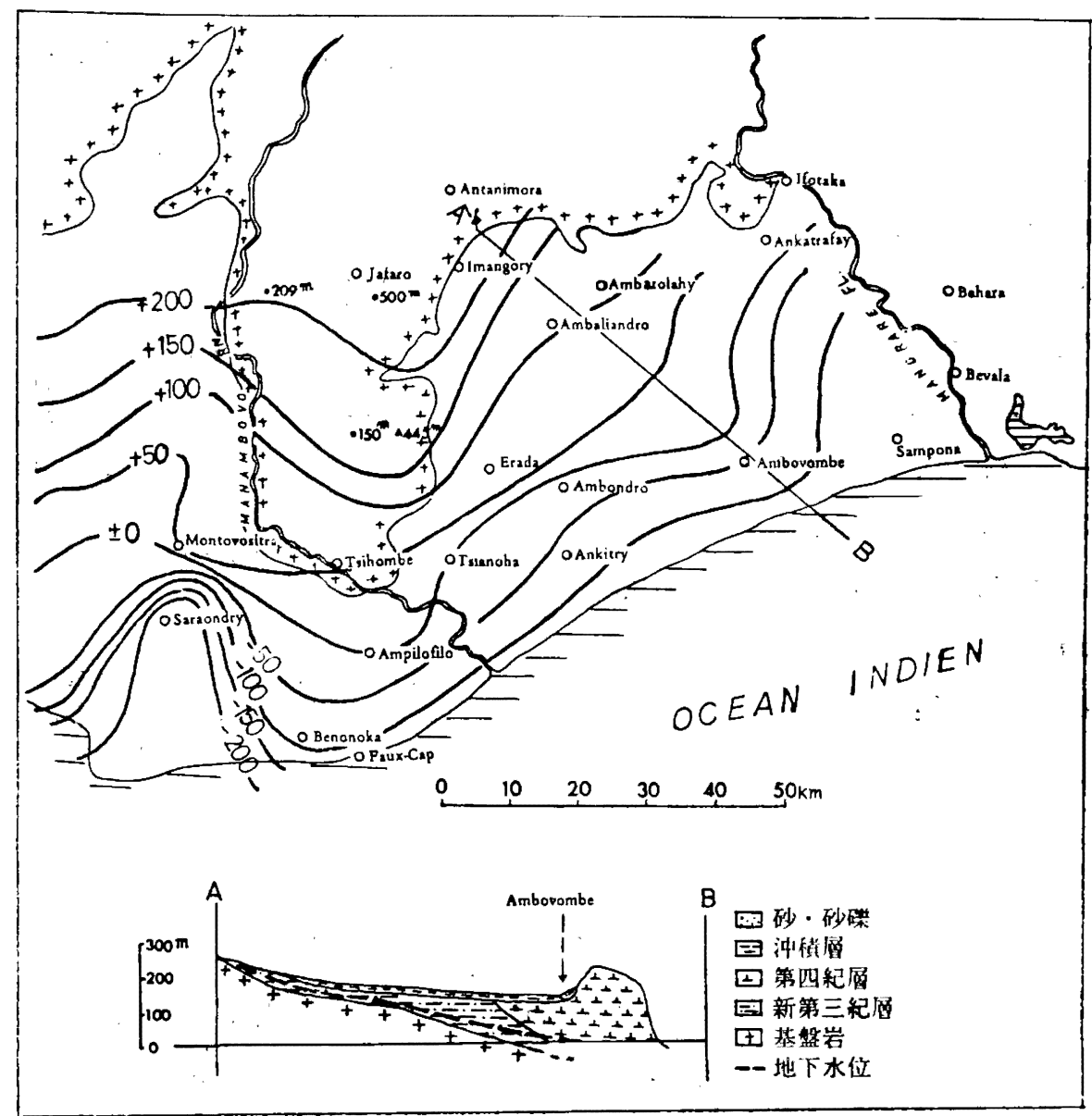

図一 5 基盤岩の等深度袙之断面図

(RAKOTONDRAINIBE, 1976 による)

Fig. 5 Bedrock topography contour and cross-section.

(after RAKOTONDRAINNIBE Jean Herivelo, 1976)

リート枠の浅井戸で容易に取水することができる。

また海岸線に接する標高 $3 \sim 10 \mathrm{~m}$ の一帯の, 水位 が標高 $0 \mathrm{~m}$ 付近にある地下水もこれと一連の地下水 と考觉らる。この一帯には10数井のボボ（すぼり V 字形の原始的な井戸)，コンクリート枠井戸が分 布 し，海岸奇りの高台の住民および家畜の貴重な水源 となっているが，海岸に近いこともあり，塩分濃度 が非常に高い。

一方アンボボンペ盆地扰よび他の 2 高原一帯は, 現在全く送電が行なわれていないため，水中モータ 一ポンプの使用が困難である。したがって水位が $100 \mathrm{~m}$ を越す場合は，揚水が不可能に近くなる。す
っとも大口径の深井戸による手服みの井戸とするこ とも 1 つの方法であるが，それたは掘さく費用が大 幅にかさむことになる。

このよらなことから，当地域の深井戸の開発を一 応の目安として，水位は $100 \mathrm{~m}$ 以浅であることが必 要条件となろら。困一7は水位が地表から $100 \mathrm{~m}$ 以 上と推定される地帯が示されている。

（3）掦水置と水貿

深井戸の揚氷量については，記録のないすのが週 半数を占めている。記録の残っているものについて は， 1 井当りの掦水量が $1 \mathrm{~m}^{3}$ 時以下のものもある が，お拈よそ $1.5 \mathrm{~m}^{3} /$ 時〜 $2 \mathrm{~m}^{3}$ 時 程度となってい 


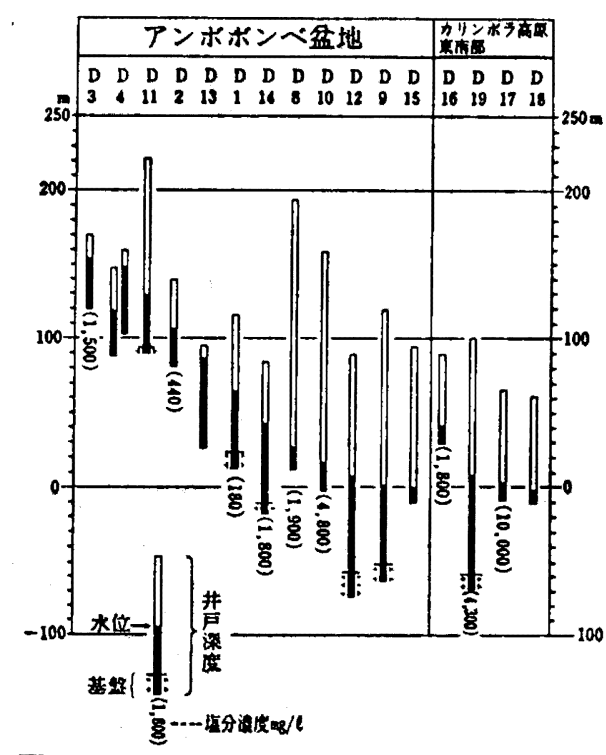

图一6深井戸の深度と水位および墥分湌度

Fig. 6 Well depth, water level, and salinity concentration in deep wells.
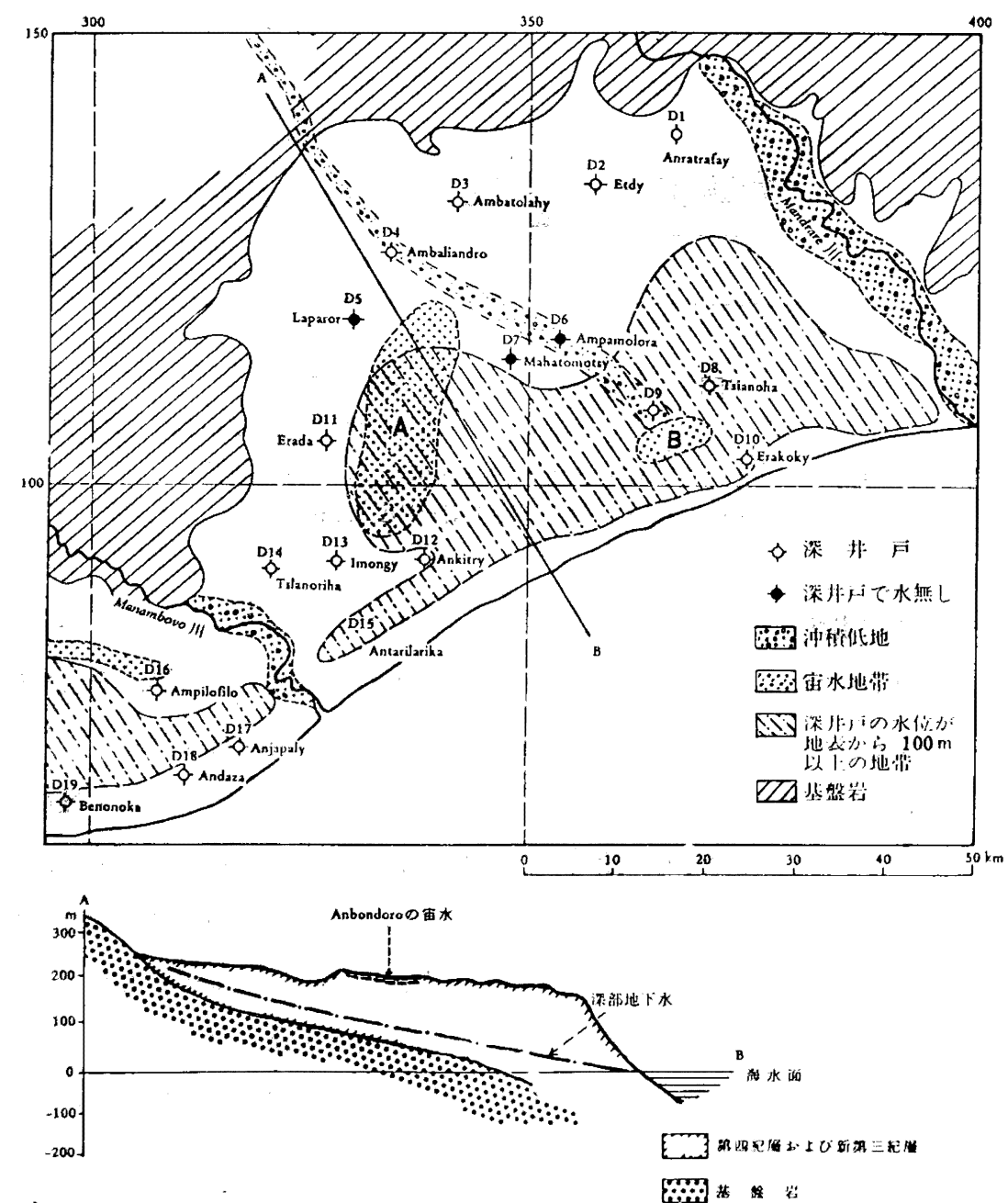

図一？アンホボンベ盆地の地下水分布図

Fig. 7 Groundwater distribution in Ambovombe Basin 
深井戸の水質についても，すべて掘さく時の記録 である。北部の基盤岩に近いD 1 井の塩合濃度 180 $\mathrm{mg} / l, \quad \mathrm{D} 2$ 井の塩分濃度 $440 \mathrm{mg} / l, \quad \mathrm{D} 3$ 井の塩分 濃度 $1,500 \mathrm{mg} / \mathrm{l}$ と良質なのに対し，中間部の D 8 井の塩分濃度 $1,900 \mathrm{mg} / l, \quad \mathrm{D} 14$ の塩分濃度 1,800 $\mathrm{mg} / l$ ，またマナンボボ川の右岸の比較的内陸側の $\mathrm{D}$ 16井です $1,800 \mathrm{mg} / l$ となっている。一方海岸際, D 10, D19井の塩分濃度は $4,000 \mathrm{mg} / l$ 台, D17井では $10,000 \mathrm{mg} / \mathrm{l}$ などの記録があり, 海岸方向に向って 塩分濃度が激增している。

海岸線に接する浅井戸群の塩分濃度は 5,000 6,000 mg/l のものか大部分を占めている。

（4）深井戸の現状

北部基盤岩に近い一帯と海岸線一帯では, 一連の 深部地下水は，水位が浅いため，手掘りによる浅井 戸で取水されている。しかし，管井の深井戸となる と，記録に残っているすのだけです，罒6，図7に 示される通り10数井以上があるが，このすべてが現 在使用されていない。なお深井戸の掘さく時期は 1950年代から1960年代のもが多く1970年代のものは 非常に稀となっている。

次にこのように休止あるいは廃止されている水源 の一例を次に記す。

調查した深井戸の 1 つに，カリンボラ高原のベヌ ヌカ部落のものがある(D19井)。この井戸は口径 8 吋, 深度 $166 \mathrm{~m}$ (基盤に到達している), 水位が $92 \mathrm{~m}$, 揚水量が $2 \mathrm{~m}^{3}$ /時 と記録されて牤り，エンジンとピ ストンポンブが設置されていた。ここでは1973年に 故障したのを最後に，修理されることなく現在に到 っているといらことである。稼動当時は鉄製の喬架 水槽も設けられて括り，この地方としては特に立派 な施設であった筈である。現在では倒れた高架水慒 は腐蝕するにまかせ，再び使用することができない 状態である。この州戸の竣工は1961年であるから， 約12年間は稼動したことになる。この施設は当地域 として長期間に渉って利用された例である。
当地域の深井戸の場合，水位の非常に低いものが 多く，揚水に無理をきたし，動力（エンヂンあるい は風車）・ボンプが故障しやすいことも事実であ る。また半乾燥地域といった苛酷な自然状件（㟋 風・台風・砂フラシ）す故障の一因ともなっていよ 5。

また深井戸施設は，政府あるいは国外機関の援助 などによる他力によるものが殆んどである。したが って一旦故障すると，地方機関あるいは住民には篮 理する費用も技術も持ち合せがないことから放衰さ れるケースが多いものと考えられる。

2) 宙水

（1）フンボンドロ宙水帯

アンボボンベ盆地の宙水帯の1つ, アンボンドロ 宙水带は, 図一 7 のA印であり, 2 百数 $10 \mathrm{~km}^{2}$ の広 い範用を占める。第四紀㒶と考号られる白色础層で 覆われた地帯であり,この白色砂の下位にはFekony と呼ばれる新第三紀の褐色の砂岩・砂賲岩からなる 地層が分布し，その Fekony が，宙水の不透水層と なっている。白色砂と Fekony とは不整合であり, Fekony が直接地表に露出するところすある。地下 水は宙水地带に一連に分布するものではない。また 年間を通じて帯水するものと, 乾季には干上るもの とがある。

フンボンドロ盯のすぐ南側には，同町住民の利用 する井戸と，家畜用のボボが一群となって分布して いる。

これらは当地方に数多く分布する寉地の 1 つの中 にある。ここの䆶地は值径䄪 $700 \mathrm{~m}$, 高低差的 $10 \mathrm{~m}$ 程度の規模をもつ。この中には生活用に作られたュ ンクリート井戸 4 井（径 $1.2 \mathrm{~m}$, 深さ $5 \mathrm{~m}$ ）と家甶 用のボボが数ケ設けられている。調查当时コンクリ 一ト井戸は 2 井が使用され，残りは空井戸となって いた。

これらの水源は，淕地の中心部一率には全く設け られておらず，その周緑部の一番外側に生活用据 


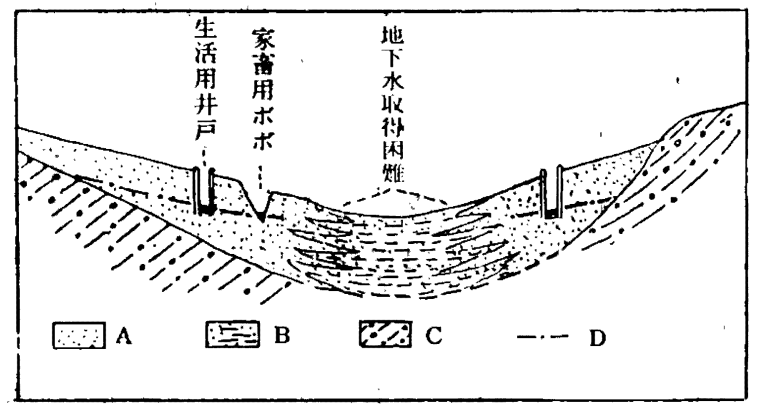

图一８ アンボンドロ町南部㕠地の宙水列

Fig. 8 Perched water in shallow basin in the south of Ambondro.
A ：白色砂の粗粒部、
C：裸色砂岩と砂碎岩、
B：白色砂の細粒部、
$\mathrm{D}$ ：宙水の水位

戸，その内側に家畜用ボボが配㯰されていた。この ことについて，マダガスカル政府技術者の説明によ れば，図ー8に示したよらに，帯水層となっている 白色砂が, 窪地の中心に向って, 粗粒から細粒堆積物 に移化するため，中心部一帯では不透水層に近い性 質となっており，地下水は殆んど得られないという
ことであった。この中の生活用井戸 2 井はそれぞれ $1,200 \mathrm{mg} / l, 4,000 \mathrm{mg} / \mathrm{l}$ の塩分濃度を示し, 近接し た井戸（約10m）でありながら，大きな差が認めら れる。巨視的には，水質も中心に向うにしたがって 塩分濃度を增やすことになり，家音用のボボが，生 活用井户の内側に設けられる形となっている。

国際協力事業団（1981）によると，井戸扰よびボ ボは，この宙水帯に約 500 籄が散在し，乾 季でも 100 ケ程度が使用されており，その汲み上げ量は $150 \mathrm{~m}^{3} /$ 日と推定されている。また宙水帯の住民が使 用する外に，海岸寄り高台の住民のらちの 15,000 20,000人に対し，この水が売買されているとい5。

（2）アンボボンべの宙水帯

も51つの宙水帯は, 図一 7 の中のB印である。 アンボボンベ市を中心としそれをとりまく，40km² の範围にあり, アンボンドロの宙水帯に比べて小規

\section{表一 4 水 霓 表}

Table 4 Chemical quality of water.

\begin{tabular}{|c|c|c|c|c|c|c|c|}
\hline \multirow[t]{2}{*}{ ' } & \multirow{2}{*}{ 名 } & \multicolumn{2}{|c|}{$\begin{array}{l}\text { アンボソドロ } \\
\text { 宙 水 带 }\end{array}$} & \multicolumn{2}{|c|}{$\begin{array}{l}\text { アンボボンベ } \\
\text { 笛水 帯 }\end{array}$} & \multicolumn{2}{|c|}{ 天 水 淄 } \\
\hline & & ( I ) & 病院内（V) & $\left(S_{1}-1\right)$ & $\mathrm{K}_{2}$ & Ambanisarika & Mokofo \\
\hline & 探 水 層 & & & I曯 & II 層 & & \\
\hline , & $\mathrm{pH}$ & & & 6.8 & 7.0 & & \\
\hline & $\mathrm{HCO}_{3}(\mathrm{ppm})$ & 991.6 & $\varepsilon 2.4$ & 390.5 & 250.2 & 82.3 & 103.7 \\
\hline & $\mathrm{Cl}^{-}(\mathrm{ppm})$ & 811.3 & 545.3 & 931.0 & 345.8 & 12.0 & 17.3 \\
\hline & $\mathrm{NO}_{2}(\mathrm{ppm})$ & 1.5 & 0.1 & 0.05 & 0.1 & & \\
\hline & $\mathrm{NO}_{3}(\mathrm{ppm})$ & 55.2 & 64.4 & 92 & 6.9 & & \\
\hline & $\mathrm{NH}_{4}(\mathrm{ppm})$ & 0.5 & $\ll 0.5$ & $<0.5$ & $<1.0$ & $<0.5$ & $<0.5$ \\
\hline & $\mathrm{SO}_{4}^{2-}(\mathrm{ppm})$ & 192.6 & 73.6 & 183.5 & 34.2 & & 0 \\
\hline & 全硬度 $\mathrm{CaCO}_{3}(\mathrm{ppm})$ & 210 & 470 & 516 & 158 & & \\
\hline & $\mathrm{Ca}^{2+}(\mathrm{ppm})$ & 38.4 & 63.2 & 115.2 & 44.8 & & \\
\hline & $\mathrm{Mg}^{2+}(\mathrm{ppm})$ & 27.7 & 75.8 & 55.4 & 11.2 & & \\
\hline & $\mathrm{Mn}^{2+}(\mathrm{ppm})$ & $\ll 0.05$ & $<0.3$ & $\ll 0.05$ & $<0.05$ & $<0.05$ & $\ll 0.05$ \\
\hline & $\mathrm{Fe}^{+}(\mathrm{ppm})$ & $\ll 0.1$ & $\ll 0.1$ & $\ll 0.1$ & $\ll 0.1$ & $<0.1$ & $\ll 0.1$ \\
\hline & 電気伝導度 $(\mu \gamma / \mathrm{cm})$ & 4,500 & 2,800 & 4,690 & 1,470 & 570 & 550 \\
\hline & 蒸発残留物 $(\mathrm{ppm})$ & 2.748 & 1,773 & 3,148 & 679 & 151 & 142 \\
\hline & 強熱残留物 (ppm) & 2,325 & 1,181 & 2,185 & 559 & 66 & 70 \\
\hline
\end{tabular}

（国際溇力可業汀，1981から引用，分析はマダガスカル地饮調查所） 
模である。

ここの宙水帯は, アンボンドロの宙水带とは買な った形態を示す。すなわち図一 7 に示したように, この宙水带は, 北西方向約 $50 \mathrm{~km}$ の基盤岩地带のア ンタニモラからほぼ值線状澄達する沖積低地（雨 季の及表流水が流れる）の末端部に当って扣り，摽 高は $120 \mathrm{~m}$ 台である。一方その南では急に高度を 150～200 m に增して，海岸寄り高台に接している。

宙水の帯水層は, 沖積堆物と考吕られる褐色砂で ある。

国際協力事業団（1981）によれば，この宙水は深 度 $15 \mathrm{~m}$ 附近と $25 \mathrm{~m}$ 附近の上下 2 層の带水層がある。 浅い第 1 帯水層については, すでに開発されつくし た感があるのに対し，第 2 帯水層は，同市の南部一 帯のみに発達し，その利用度は比較的少ないことか ら，今後の開発に期待できるとしている。現在これ らの宙水を対象とした井戸・ボボ合わせて約 100 ケ が分布しているが，ここではそれらがすべて個人の 所有物となっているといら。限られた数の井戸主 は, アンボボンベ市民約 3 万人に水を売って，収入 を得ていることになる。

宙水地帯の井戸およびボボの所有者にとっては, そこで得られる地下水が重要な財産となっている。 このように古くからの習慣として，水の䒿手・買手 に2 分された社会の中に，新たに公的な水の開発が 行なわれた場合，売手側にとってい恒久的な財産と 考えていた水源の価值は，一度に下落してしまうこ とになる。当地域の水の開発が必要であることは， 論を待つまでもないが，ここにはそのことにより直 接不利益をこうむる多数の水の売手住民が存在する といらことをす認識して拉く必要がある。

$$
\mathrm{V} \text { あとがき }
$$

マダガスカル南部地域は，半薜燥地域に属し，雨 量が少なく，水問題の全面的な解決は難しい。しか
し, アンポボンベ盆地の東側には，乾季のもっとる 流量の少ない月でも, 約 $10 \mathrm{~m}^{3}$ 程度が流れている? ンダラレー川がある。

同河川は, 水不足の地域の一つの重要水源であり, 公共の給水車あるいは，私的な牛車によって運搬・ 給水されている。

すでにカリンボラ高原では，同高原を横断するハi イプラインが，FED資金によって，具体化しつつ ある。

アンボボンベ盆地においても，海岸寄り高台を横 断する，パイプラインの実現が可能であれば，同地 方の水問題は，扣括かた解決されるであろう。しか し，現時点では，それに見合う経済效果にも期待で きないことや, 揚程が $300 \mathrm{~m}$ にもおよ゙送水ポンブ の運転特よびパイプラインなどの長期に涉る維持管 理の可能性についても不安がある。一方わが国とし ても 1 発展途上国への無償援助としては，本計画は 愿大に過ぎる感がある。

このよらなことから当面の生活用水の確保には, 海岸奇り高台での天水溜の增設扣よび改修，単独詝 水槽の建設, 2 つの宙水帯に打いて公共の水源数井 を新設することはた給水車の供与などが挙げられ る。

先ず天水溜の增強により, 天水の取得が增加す る。一方給水車によって, 表流水和よび宙水带の水

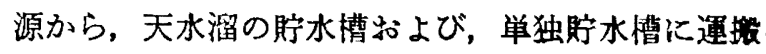
され，住民に配分するといった方法が取られること になろう。

深井戸の開発については，次のようなことになろ ら。海岸寄り高台のうち，罒一7に示すように，そ の大部分は, 地下水位が地表から $100 \mathrm{~m}$ 以深と推定 され，ここでの深井戸開発は，現段階では困難であ る。しかしその西側のマナンボボ川両岸一带, 海岸 際の高度の若干低い一带（標高 $100 \mathrm{~m}$ 以下の地带） などは，一応開発可能地帯とみなし得る。また北部 のD 2 井などは，水位50 $\mathrm{m}$ 以内の記録があり，水質 
も良質であり,この一帯も開発可能であろう。

深井戸は, 宿水帯の浅層地下水に比へ, 水位の变 動がそれ程なく，年間を通じてコンスタントに取水 が可能であるし，人畜による污染を防ぐうえでも利 点がある。一方マダガスカル政府では，水理地質の 専門家による南部地域の地下水の研究が，長年に涉 り実施されており,さく井技術者も荃成され，国内全 域で活篗している。政府质有のさく井機は耐用年数 を越す老朽機が多い。したがってさく井機扎よびそ の附带機材が供与されれば，マダガスカル政府機関 で充分深部地下水の開発ができるものと判断され， 将来それらの一式が供与される予定となっている。

最後に過去に開発された潹井戸施設が, 現在すべ て使用されていないといった問題にふれる。

このような折角巨額を投して作られた深井戸施設 が, 故障以後放置されているといった現象は，単に マダガスカルのみの問題ではなく, 乾燥地域・半乾 燥地域の後進地域といったところに，共通する事が らであり，援助する側も充分考虑されなければなら ない。

こらいった地域の深井戸および施設は，単純・堅 牢でありかつ維持費がなるべくかからないといった ことが重要な条件となろら。

例えば上半部が大口径とし，下部は小口径の接合 井戸とする。この場合住民はバケツによって汲み上 げることができる。

また接合井でない場合でも，水位の浅い場合は手 押しポンプ, 足ぶみポンプとし, 故障の多い風車井 戸は，水位の深い井戸のみに使用することなども必
要であろう。然料費のかかるェンヂン・発電機など の使用については，自力で脣期の䗬転が可能である かどうか，事前に充分愉討されるべきである。

井戸施設あるいは，さく北機などの，スペア・ハ 一ツなどを，当初から余分に準借することも，こ5 いう地域には重要なことである。一方深非戸施設一 さいの修理执よび管理のできる技術者を養成し，配 置すこるとあ必要である。

\section{文献}

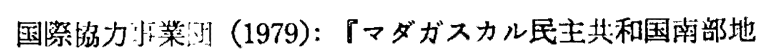
域生活用水開発計雨輩前調查報告書」101p.

国際協力苏業団 (1981): 「マダガスカル民主共和国南部地 域生活用水開発計画基本設計調查哴告请」 $35 \mathrm{p}$. 企资料 編, 210 p.

日商岩井株式会社（1973）：「マダガスカル南部地域の水盗 源調査ならびに地下氷利用に関する歓皆」49p.

森 和雄 (1980)：マダガスカルとその南部地域の水事情， 地質二ュース, 306号，44〜56。

森 和婎 ・兽我部正敏・寺溒勝二・主村清志・美谷島克美 (1980)：マダガスカル南部半瑹燥地域の水について， 日本地下水学会昭和 55 年度春季講演会講演要旨, 日本地 下水学会誌, 22, 133。

PROGRAMME DES NATIONS UNIES POUR LE DEVELOPPEMENT (1971): STRATEGIE DU DEVELOPPEMENT REGIONAL DE LEAU DANS LE SUD MADAGASCAR. 39p.

RAKOTONDRAINIBE Jean Herivelo (1976): HYDROGEOLOGIE DE L'EXTREMESUD (ZO-NE COMPRISE ENTRE LE MANDRARE ET LE MANARANDRA). p 45.

Service Geologique de Madagascar (1957) : CARTE HYDROGEOLOGIQUE du Sud de Madagascar. （受付：1981年12月15日，受里：1982年 1 月30日） 